\title{
The 2000 western Tottori earthquake
}

\author{
Yasuhiro Umeda \\ Disaster Prevention Research Institute, Kyoto University, Uji, Kyoto 611-0011, Japan
}

(Received August 27, 2002; Revised September 12, 2002; Accepted September 12, 2002)

1. The 2000 Western Tottori Earthquake — Seismic activity revealed by the regional seismic networks - . . 819

2. Swarm-like seismic activity in 1989,1990 and 1997 preceding the 2000 Western Tottori Earthquake .... 831

3. Spatial analysis of the frequency-magnitude distribution and decay rate of aftershock activity

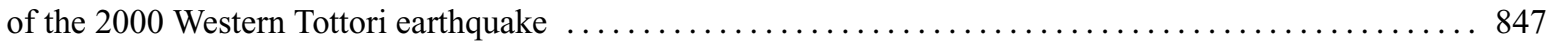

4. Local site amplification and damage to wooden houses in Shimoenoki, Tottori, Japan, by the

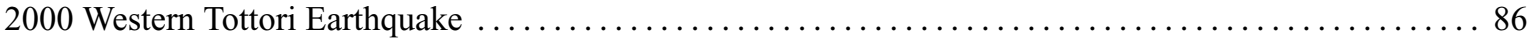

\section{Preface}

The earthquake of magnitude $\mathrm{Mj} 7.3$ (Mw 6.8) occurred at 13:30 (JST) on October 6, 2000, in the western part of Tottori prefecture, Honshu, Japan. In the epicentral area, a maximum JMA intensity of ' 6 higher' was recorded. No one was killed, but more than 130 peoples were injured and 149 houses completely collapsed. In this region, the seismic activity has been high along the sea of Japan coast. The large historical earthquakes, recent swarm earthquakes, volcanos and hot springs are distributed within the belt zone along the coast. The 2000 western Tottori earthquake was the first large event to occur following the completion of several large instrumental networks in Japan, including Hi-net (High Sensitivity Seismograph Network), KiK-net (Kiban Kyoshin network), K-NET (Kyoshin Network) operated by the National Research Institute for Earth Science and Disaster Prevention (NIED, 2002) and GEONET (GPS Earth Observation Network) operated by the Geographical Survey Institute(Hatanaka et al., 2001a, b). The hypocenters of the main shock and aftershocks were determined in near real time and were available to the public from NIED. The fault plane solution of the main shock was rapidly obtained from the GPS data. The inferred fault had a length of $20 \mathrm{~km}$, a width of 10 $\mathrm{km}$, and a dip angle of nearly 90 degree (Geographical Survey Institute, 2001). The aftershock distribution coincided with the strike of this fault model. Clear surface faulting could not be found, probably because the earthquake faulting reached a depth of only $1 \mathrm{~km}$, not reaching the surface. But, some cracks oriented parallel to the estimated fault were found on a paved road (Geological Survey of Japan, 2001). In the headrace tunnel $200 \mathrm{~m}$ below the surface near the source region, systematic right-lateral displacements of 10 $\mathrm{cm} \sim 20 \mathrm{~cm}$ were found in a concrete lining (Ueta et al., 2002).

The earthquake occurred in an area of low density of active faults. The Kamakurayama south fault with a trend of

Copy right(C) The Society of Geomagnetism and Earth, Planetary and Space Science (SGEPSS); The Seismological Society of Japan; The Volcanological Society of Japan; The Geodetic Society of Japan; The Japanese Society for Planetary Sciences.
ENE-WSW is the only identified fault in this area, but it is mapped with only low accuracy. The strike of the estimated fault was conjugate to the Kamakurayama south fault, so, this fault was not activated in this earthquake. The seismic activity has been high in the western part of Tottori prefecture and in the border area of Tottori-Shimane prefectures. In the epicentral area, swarm-like earthquakes, including magnitudes of 5.1 to 5.3 events have occurred four times since 1989. The foci of the swarm-like earthquake were determined using combined data of the Tottori observatory and temporary seismic station observations (Shibutani et al., 2002). During each of the four swarms, the epicenters were distributed in a NNW-SSE direction, which is similar to the fault strike of the recent main shock. The hypocenters of the four swarms were distributed within a depth range from $5 \mathrm{~km}$ to $12 \mathrm{~km}$. But, the distribution of hypocenters of the four swarms did not overlap. The locations of these previous swarms were compared to the slip distribution of the 2000 earthquake, which was obtained by inverse methods using K-NET and KiK-net data (Iwata and Sekiguchi, 2002). The large slip of the main shock was distributed mainly to the south on a shallow portion of the fault, which was outside of the regions where the swarms occurred.

A first temporary seismic observation was carried out to obtain the details of the aftershock distribution, deep structure of the earthquake fault and the velocity structure in the source region. In the region south of the epicenter, where the moment release during the mainshock was large, the aftershock activity was low and distributed narrowly along the estimated fault. In contrast, in the northern region, the aftershock actvitiy was higher and dispersed over a wider region. From the scattered distribution of aftershocks and the gap in the leveling data by the Geographical Survey Institute, a branching fault was inferred in the north region (Sagiya et al., 2002). Observations of trapped waves, which are the guided waves propagating along the fault, suggest that the parallel faults on the surface are connected at deeper portions (Nishigami et al., 2002). The $b$-value of the frequency-magnitude distribution and the $p$-value of the 
modified Omori law, describing the decay rate of aftershock activity were investigated by using more than 4000 aftershocks. Both $b$ - and $p$-values are larger in the region around the epicenter of the main shock and have smaller values in the northwest region. The high $b$ - and $p$-values may be explained by the relatively low stress caused by former swarm activity and large slip during the main shock. Areas with relatively low $b$ - and $p$-values are probably regions under higher applied shear stress after the main shock (Enescu and Ito, 2002).

Shimoenoki village, located about $10 \mathrm{~km}$ southeast of the main shock epicenter, suffered remarkable damage, particularly to residential wooden houses. From the damage distribution based on a survey of all wooden houses, the local site-amplification characteristics estimated from aftershock records, and the transfer functions of wooden houses evaluated using microtremors, the spatial variation of damage appears to be attributed to the variation in site-amplification factors at frequencies between 2 and $5 \mathrm{~Hz}$. This is close to the first natural frequency of wooden houses (Matsunami et al., 2002). Severe damage of wooden structures was also observed on the Yumigahama Peninsula, which is an arc-shaped sand bar $20 \mathrm{~km}-35 \mathrm{~km}$ north of the epicenter. The lateral variation of the basement structure was identified from the combined analyses of aftershocks, gravity and microtremors. It was found that the depth to bedrock drops suddenly in the central part of the peninsula to a depth of $900 \mathrm{~m}$ compared to the shallower depth to bedrock in the south (Yoshikawa et al., 2002).

A wide-band magnetotelluric (MT) sounding survey was conducted in and around the focal area. A low electrical resistivity (100 Ohm-m) region was found just under the main shock (Shiozaki et al., 2001). Between October 1997 and the time of the 2000 earthquake, four low frequency earthquakes occurred at a depth of $30 \mathrm{~km}$ just under the main shock hypocenter (Ohmi et al., 2002). These observations suggest the existence of the fluids. Why do fluids exist in this region? If the Philippine Sea plate extends to under the Sanin coast, the fluids may be squeezed out from the subducting plate. In addition, these fluids may explain the damaging earthquakes, volcanos and hot springs which are distributed within the belt zone along the Sanin coast. In order to confirm the existence of the subducting plate at depth, a secondary seismic observation has been carried out in the area from the Chugoku district over to Shikoku. This observation started by cooperative efforts of the national universities and the Japan Marine Science and Technology Center during 2002.

\section{References}

Enescu, B. and K. Ito, Spatial analysis of the frequency-magnitude distribution and decay rate of aftershock activity of the 2000 Western Tottori earthquake, Earth Planets Space, 54, this issue, 847-859, 2002.

Geographical Survey Institute, Crustal movements in Chugoku district, Rep. Coord, Comm. Earthq. Predict., 65, 592-618, 2001 (in Japanese).

Geological Survey of Japan, Surface rupture associated with the 2000.10.6 Tottoriken-seibu earthquake, Rep. Coord, Comm. Earthq. Predict., 65, 630-634. 2001 (in Japanese)

Hatanaka, Y., M. Sawada, A. Horita, and M. Kusaka, Calibration of antennaradome and monument-multipath effect of GEONET-Part 1: Measurement of phase characteristics, Earth Planets Space, 53, 13-21, 2001a.

Hatanaka, Y., M. Sawada, A. Horita, M. Kusaka, J. M. Johnson, and C. Rocken, Calibration of antenna-radome and monument-multipath effect of GEONET - Part 2: Evaluation of the phase map by GEONET data, Earth Planets Space, 53, 23-30, 2001b.

Iwata, T. and H. Sekiguchi, Source Model of the 2000 Tottori-Ken Seibu earthquake and near-source strong ground motion, Proc. 11th Japan Earthq. Eng. Symp., 2002, (in Japanese with English abstract)(in press).

Matsunami, K., T. Morii, Y. Okamoto, and T. Fujiwara, Local site amplification and damage to wooden houses in Shimoenoki, Tottori, Japan, by the 2000 Western Tottori Earthquake, Earth Planets Space, 54, this issue, 861-870, 2002.

NIED, http://www.hinet.bosai.go.jp/jishin_portal/ index_e.php, 2002

Nishigami, K., I. Doi, T. Mizuno, K. Tadokoro, and A. Shimokawa, Probe into the earthquake source fault of the 2000 Western Tottori earthquake, Chikyu Monthly, No. 38, 174-181, 2002.

Ohmi, S., K. Watanabe, T. Shibutani, N. Hirano, and S. Nakao, The 2000 Western Tottori Earthquake-Seismic activity revealed by the regional seismic networks-, Earth Planets Space, 54, this issue, 819-830, 2002.

Sagiya, T., T. Nishimura, Y. Hatanaka, E. Fukuyama, and W. L. Ellsworth, Crustal Movements Associated with the 2000 Western Tottori Earthquake and its Fault Models, Zisin, 54, 523-534, 2002 (in Japanese with English abstract).

Shibutani, T., S. Nakao, R. Nishida, F. Takeuchi, K. Watanabe, and Y. Umeda, Swarm-like seismic activity in 1989, 1990 and 1997 preceding the 2000 Western Tottori Earthquake, Earth Planets Space, 54, this issue, 831-845, 2002.

Shiozaki, I., N. Oshiman, E. Adachi, T. Uto, R. Hirai, K. Maeda, R. Yoshimura, H. Murakami, S. Yamaguchi, H. Nishiyama, K. Matsuyama, T. Noguchi, and S. Yabe, Preliminary Investigation of the deep crusta resistivity structure in the focal region of the 2000 western Tottori prefecture earthquake, southwestern Honshu Japan, Annuals of Disas. Prev. Res. Inst., Kyoto Univ., No. 44 B-1, 293-303, 2001 (in Japanese with English abstract).

Ueta, K., K. Miyakoshi, and D. Inoue, Left-lateral Deformation of Headrace Tunnel Associated with the 2000 Western Tottori Earthquake, Zisin, 54, 547-556, 2002 (in Japanese with English abstract).

Yoshikawa, H., H. Morikawa, J. Akamatsu, T. Noguchi, and R. Nishida, Estimation of the Bedrock Structure at Yumigahama Peninsula, Tottori, by Using Observation of Aftershocks, Microtremors, and Gravity, Zisin, 55, 61-73, 2002 (in Japanese with English abstract).

Y. Umeda (e-mail: umeda@rcep.dpri.kyoto-u.ac.jp) 